Анђелка Н. Митровић

Катедра за оријенталистику

Филолошки факултет

Универзитета у Београду

e-mail: andjelkam@fil.bg.ac.rs
378: 811.411.21(497.1)

https://doi.org/10.18485/ai_lik.2020.6.9.4

Оригинални научни рад

\title{
НАСТАВА АРАПСКОГ ЈЕЗИКА И КЊИЖЕВНОСТИ НА ЈУЖНОСЛОВЕНСКИМ ПРОСТОРИМА
}

Историја европске оријенталистике и арабистике, чији су југословенска и српска оријенталистика/арабистика део, сеже више векова уназад. Почетак наставе арапског језика у Европи везује се за 13. век, а организационо за Свету столици. И на јужнословенским просторима учење оријенталних језикаи ма такође дугу традицију. Од 14. веку највећи део јужнословенских територија постао је део Османске империје. Исламизација, коју је она донела, наметнула је и нови систем образовања, а са њим и наставу арапског језика. На универзитетском нивоу, настава арапског језика почиње отварањем Семинара за оријенталну филологију у Београду 1926. године.

Кључне речи: оријенталистика, арапски језик, арапска књижевност, катедре, наставни модели, Београд, Сарајево, Софија

Оријенталистика као „еминентно европска духовна и знанствена творевина“ (Jauk Pinhak 1977: 10) коначно се оформила тек у 19. веку, али су се оријентални језици предавали још од 13. века у више европских градова. На настанак оријенталистике у Европи утицали су различити интереси и мотиви, различите историјске околности у којима су се успостављали контакти и развијали односи између Истока и Запада, при чему је религијска сфера имала веома значајну улогу. Интересовања хришћанске Европе за 
Исток и ислам потекла су, првенствено, из Рима, седиште западног хришћанства. Света столица се, пре свега, концентрисала на протеривање ислама са Иберијског полуострва што је и остварено падом Гранаде 1492. године. После раскола 1054. године, најзначајнија мисија за Свету столицу и папе била је враћање католичкој матици расколничких цркава, каквих је било много у северној Африци (монофизити, несторијанци, јакубити...). За деловање и на једном и на другом подручју мисионарима је било неопходно солидно знање арапског језика и познавање свеукупних реалија арапског говорног простора. Због тога се, при већим католичким центрима, отварају курсеви арапског језика за мисионаре, а 1250. године и прва катедра у Риму. Почетком 14. века Света столица оснива читав низ катедара за арапски, хебрејски и арамејски језик у Риму, Паризу, Оксфорду, Болоњи... Прва лаичка катедра за арапски језик основана је у Париз 1539. године (Collège de France) заслугом мисионара Г. Постела (Guillaume Postel; 1510-1581). У другој половини 16. века отворена је катедра на Универзитету у Лајдену, почетком 17. века у Оксфорду, а током 18. века арабистичке катедре ничу по читавој Европи (Rodinson 1974: 9-62).

И на јужнословенским просторима учење оријенталних језика има дугу традицију, али и потпуно другачије циљеве од оних на Западу. У 15. и 16. веку највећи део јужнословенских територија био је под османском влашћу, захваћен процесом исламизације. Исламизација је донела са собом и нови систем образовања везан првенствено за џамије и текије. Уз њих, значајно место су заузимале муслиманске основне школе (мектеби), којих је било по свим насељима, односно средње школе (медресе) отваране по већим градовима. Настава у њима обухватала је учење главних оријенталних језика - арапског, турског и персијског, читање текстова из Курана, као и још неке верске науке, попут исламског права, филозофије и слично. Најпознатије медресе биле су сарајевска, београдска и скопска. У 19. веку, а особито потпадањем Босне под аустроугарску власт извршена је реформа школства, у коме и даље опстају медресе, али се појављују и реформисане ниже средње школе (рушдије). 
Године 1879. отворене је у Сарајеву реална гимназија, из које је 1883. настала класична гимназија, где су се уместо класичних језика - грчког и латинског - учили оријентални језици - арапски, турски и персијски. Нешто касније отворене су и Шеријатско-судачка школа (1887) и шеријатска гимназија (1918), које су обезбеђивале кадрове за судство, управу и верске школе. У свим поменутим школама арапски језик је био обавезан предмет јер је за изучавање класичних исламских теолошких и филолошких наука знање арапског било неопходно (Ramić 1987).

Специфичан географски положај Балканског полуострва, где се, у цивилизацијском смислу, „као и у Шпанији, развијао један самосвојни, аутентични 'европски ислам" (Vukomanović 2003: 24) и преко кога је ишла и иде граница између ислама и неислама, као и вишевековно присуство Османлија на јужнословенским просторима, одредили су улогу оријенталне компоненте у националном идентитету балканских земаља. Оријентално наслеђе је у великој мери обележило свеукупну културу балканских народа, па је отуда оријентална компонента на балканским просторима незаобилазна и трајно присутна тема више националних наука - историје, књижевности, етнологије, културне историје, историје архитектуре и других, а пре свега оријенталне филологије и оријенталистике. Током 18. и 19. века, када се оријенталистика као наука потпуно конституисала у Европи, читава јужнословенска регија налазила се у саставу Османске империје, па је, за Европу, и у географском и у културно-цивилизацијском смислу, то био Оријент. Један од предуслова за васпостављање научне оријенталистике на јужнословенским просторима био је повлачење Османског царства чиме је он престао да буде Исток у државно-административном смислу. Паралелно са повлачењем Османлија, на овом простору одвијао се и процес европеизације и модернизација друштава, што је омогућило заузимање неопходне дистанце према оријенталној компоненти и њено објективно вредновање, а тиме и настанак науке о Истоку. Крајем 19. и на самом почетку 20. века оријенталистичка делатност на јужнословенским просторима се сводила на обраду и 
издавање оријенталних рукописа - на турском и арапском језику, али не на научној основи. Историја научне и универзитетске оријенталистике у овом делу Европе почиње двадесетих година 20. века. Катедра за оријенталне језике на универзитету у Београду била је тада „једини светионик те науке на Балкану, а први организатор тог студија проф. Др. Фехим Бајрактаревић једини научни оријенталиста, који је са неколико добрих радова већ уведен у ред светских оријенталиста“ (Окић 1934: 403-404). Професор Фехим Бајрактаревић, оснивач Катедре и један од најистакнутијих пионира балканске научне оријенталистике, својим преданим вишедеценијским педагошким и научним деловањем, учинио је много на утемељењу, развоју и афирмацији југословенске науке о Оријенту. У свом концепту он је објединио „све компоненте које реални, историјски Исток објективно осветљавају у свим његовим - за Балкан значајним аспектима. Кренувши овим путем он је, својим радовима, уздигао југословенску оријенталистику до нивоа европске науке“ (Букановић 1963: 3-4)

Различит статус и различита историјска судбина појединих јужнословенских регија, утицали су на стварање разнородне етно-конфесионалне структуре становништва, и разнолике културне традиције у њима. Отуда процес настанка и институционализације југословенске оријенталистике ${ }^{1}$ није свуда имао иста појавна обележја. Временом, јасно су се искристалисала два теоријско-методолошка правца њеног развоја, чији су заједнички именитељ били европски научни стандарди. Један правац је везан за Босну и Херцеговину, делом Хрватску и још нека рубна подручја, са Сарајевом као главним центром, и други за Србију (Јужна Србија/Стара Србија) и Београд.

„Под пресудним утицајем западноевропског филолошког модела и метода XIX века, југословенска научна

1 Када је реч о српској научној оријенталистици, морамо је посматрати у њеном континуитету. С обзиром на то да је настала двадесетих година прошлог века у држави која се звала Краљевина Срба, Хрвата и Словенаца и да се, упркос одређених разлика, у државама њеним наследницама, развијала као јединствен ток, све до распада СФРЈ, у оптицају је био термин југословенска оријенталистика. 
оријенталистика израста из својих преднаучних домаћих корена и уобличава се, као оријентална филологија, првих деценија нашег столећа. Сви, за сада малобројни, хроничари и историчари наше оријенталистике једногласни су у оцени да она концепцијски почива на филолошкој визији култирно-историјски и гео-политички условљених научних и практичних потреба и могућности југословенске заједнице. Другачије опредељење у оно време тешко би се могло и замислити јер је филолошки приступ био доминантан у тадашњој европској оријенталистици, а и у матичним језикословним традицијама источних народа" (Tanasković 1986: 56).

С обзиром на то да је јужнословенски простор трајно обележен оријентално-исламским печатом у материјалној и духовној култури, југословенска оријенталистика имала је одређених предности и услова за брз напредак. С друге стране, оријентална компонента била је и велики хендикеп у њеном развоју, на пример, у деловима Босне и Херцеговине, Македоније и Косова, где су истраживачи и научни радници били углавном муслимани и где су у одређеним периодима, поједини оријенталистички кругови, под политичким притисцима, подлегали националним политикама.

Систематско изучавање арапског и других оријенталних језика, на академском нивоу, на јужнословенским просторима започело је 1926. године отварањем Семинара за оријенталну филологију на Филозофском факултету у Београду. ${ }^{2}$ Њен оснивач, др Фехим Бајрактаревић (1889-

2 Више о историјату Катедре види текстове објављене поводом катедарских јубилеја: А. Митровић, „Катедра за оријенталистику“,

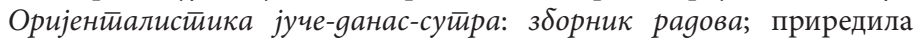
Анђелка Митровић, Београд: Филолошки факултет, 2019. 11-27; М. Teodosijević, „Ninety-One Years Of Turkish Studies In Belgrade”, Оријенйалистиика јуче-gанас-суйра: зборник раgова; приредила А, М., Београд: ФФ, 2019. 28-42; А. М., „Група за арапски језик.

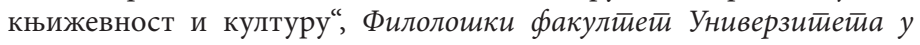
Беоіраgy, Београд, ФФ, 2016. 359-372; Љ. Чолић, „Османистика на Филолошком факултету у Београду“, Филолошки факулииети Универзийейа у Беоіраgy, Београд, ФФ, 2016. 373-376; М. Т., „Група

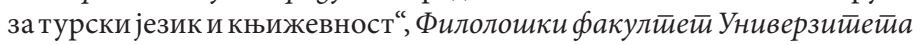
y Беоі̄pagy, Београд, ФФ, 2016. 377-383; A. M. i E. Miljković, “Celebratingthe $90^{\text {th }}$ Anniversary of the Department of the Oriental Studies at the 
1970), ${ }^{3}$ бечки студент и докторанд и у Европи већ афирмисани научник, 1925. године дошао је, на позив професора Богдана Поповића, у Београд, и на Катедри за светску књижевност Филозофског факултета почео да предаје персијску књижевност и турски, заправо, османски језик. Само годину дана касније, када је основао самостални Семинар за оријенталну филологију, мудро и научно потпуно оправдано определио се за концепцију исламолошке оријенталне филологије, односно за изучавање језика и књижевности народа који су створили исламску цивилизацију и највише допринели њеном процвату. С обзиром на чињеницу да је та цивилизација у свом османском руху непосредно или посредно утицала на нашу материјалну и духовну културу, и учинила да оријентална компонента постане битан елеменат нашег културног идентитета и наслеђа, ова концепција у потпуности је одговарала нашој националној истовремено источној и западној, понајвише балканској културној традицији" (Tanasković 1986: 51-52), и остаје трајно актуална на јужнословенским просторима. У оквирима тог, цивилизацијски и културолошки структурисаног модела, наставни план Семинара за оријенталну филологију из 1926, предвиђао је да се арапски и турски језик предају осам семестара, арапска, турска и персијака књижевност два

Belgrade University”, Human - Researchin Rehabilitation 6, 2 (2016): 4649; А. М., „Деведесети рођендан Катедре за оријенталистику“, Речи 8 (2015): 216-232; A. M., „80 godina Katedre za orijentalistiku“, Nur 15, 49/50 (2006): 21-33; A. M., „75. rođendan Katedre za orijentalistiku - 75. rođendan jugoslovenske iranistike“, Nur 10, 32(2002): 52-57; A. M., „Nastava orijentalnih jezika na Beogradskom univerzitetu“, Glossa III, 1(1997): 47-54; A. M., „Sedamdeset godina Katedre za orijentalistiku“, Orijentalistika 70: zbornik radova, Beograd, 1997. 21-28; D. Tanasković, „Šest decenija orijentalistike na beogradskom Univerzitetu“, Kulture Istoka 10 (1986): 51-52; D. T., „Prema daljim uspjesima: Pola vijeka orijentalistike u Beogradu“, Odjek XXX, 10 (1986): na str. 13 і 23; М. Ђукановић,

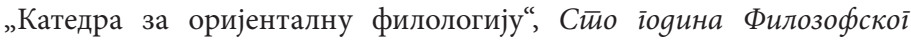
факулиметиа, Београд, 1963. 477-484 и Orijentalistika 70: zbornik radova, Beograd, 1997. 15-20.

3 Више о оснивачу наше научне и универзитетске оријенталистике види.: А. Mitrović, Naučno delo Fehima Bajraktarevića, Beograd: Filološki fakultet, 1996. 
семестра, а Увод у оријенталну филолгију само један семестар. Повремено, су увођени и једносеместрални специјалистички курсеви из османске дипломатике, арапске метрике и други. Све стручне предмете предавао је професор Бајрактаревић (Ђукановић1963).

Неколико деценија касније основане су оријенталистичке катедре и у другим југословенским градовима. У Сарајеву, на Филозофском факултету, 1950. године отворен је Одсјек за оријенталну филологију. Његови оснивачи били су пионири научне оријенталистике: Шаћир Сикирић (1893-1966), који је студирао оријенталне језике (арапски, персијски и турски) и докторирао у Будимпешти ${ }^{4}$ и Недим Филиповић (1915-1984), турколог-османиста, који је оријенталне језике студирао у Београду и Истанбулу. ${ }^{5}$ Катедра у Сарајеву имала је углавном исти наставни план као и београдска, с тим што је настава персијског језика и књижевности била далеко развијенија од самог почетка. Ни назив - Одсјек за оријенталну филологију, са катедрама/односно студијским областима за арапски језик и књижевност, турски језик и књижевност и перзијски језик и књижевност, као ни студијску концепцију она није ни до данас променила. Мада су на Катедри за арапски језик и књижевност планови и програми студија обогаћени новим предметима и наставним садржајима, задржана је класична филолошка концепција, односно изучавање арапског језика и књижевности, кроз различите предмете (колегије), као што су: Фонетика и морфологија арапског језика, Морфологија арапског језика, Морфосинтакса арапског језика 1-2, Синтакса арапског језика 1-4, Синтакса функционалних стилова у арапском језику. Настава арапске књижевности, у којој има највише иновација, обухвата следеће предмете: Стара арапска књижевност, Класична арапска књижевност, Модерна арапска књижевност 1-2, Поетика старе арапске књижевности,

4 Више о Ш. Сикирићу види: Jašar Redžepagić, „Dr Šaćir Sikirić“, Nur12, 40 (2004): 38-43.

5 Више о настанку и концепцији сарајевске катедре види.: „Odsjek za orijentalistiku“, Filozofski fakultet u Sarajevu 1950-1980, Sarajevo, 1980. 135-143. 
Поетика класичне арапске књижевности, Арапска стилистика и метрика, Савремена арапска поезија, Савремена арапска проза/Савремени арапски роман. Што се тиче културолошких предмета постији Оријентално-исламска цивилизација 1-3, а такође и општеобразовни стручни предмет Увод у оријенталну филологију. Настава је организована по циклусима, на додипломској (трогодишње студије) и дипломској МА разини, и кроз једнопредметни и двопредметни студиј, а њен циљ је да студент „по завршетку дипломског студија (...) посједује такву разину језичког знања и развијене вјештине комуникације на арапском (...) језику, те способност разумјевања и интерпретације садржаја из подручја проучавања арапског (...) језика и књижевности који га оспособљавају за послове језичног посредовања у економским, управним и културним институцијама, рад у туризму, медијима и издаваштву, те у другим секторима у којима је потребан одговарајући профил радника“. Поменути глотодидактички модел, филолошки структурисан, у коме доминирају теоријски предмети, намењен је, првенствено, развијању рецептивних језичких вештина и свакако обезбеђују студенту,способност разумјевања и интерпретације садржаја“" на арапском језику, али не и (течну) комуникацију са изворним говорницима, на пример туристима, за шта је, свакако, потребна другачија концепција студија и познавање основних говорних дијалеката арапског језика. Битно је поменути и чињеницу да се настава на Одсјеку „изводи на босанском/хрватском/српском језику као и на арапском/ турском/перзијском језику“. ${ }^{\prime}$

Овде треба додати и податак да је београдска катадра шездесетих и седамдесетих година такође била одсек, али Одсек за оријенталистику. Промена друге компоненте назива - оријенталне филологије у оријенталистику - донела је, заправо, суштинску промену студијске концепције. Оријентална филологија, по дефиницији, обухвата комплексно изучавање писаних споменика на оријенталним

$6 \quad$ https://www.ff.unsa.ba/index.php/bs/nastava-bs/odsjeci-na-ffunsa и http:// ff.unsa.ba/index.php/bs/2014-12-15-22-42-27; страница посећена 4.12. 2019. 
језицима, односно оријенталних језика и књижевности, док оријенталистика подразумева укупност свих наука чији се предмет изучавања у цивилизацијском смислу налази на Истоку - економије, историје, религије, филозофије, етнологије, археологије, културне историје, уметности, неуке... Та промена унела је, седамдесетих година, у програме нове предмете а почетком 21. века потпуно је дошла до изражаја кроз студијски профил Језик, књижевност, култура (ЈКК) на Филолошком факултету у Београду, чији је Арабистика део.

У Приштини је 1973. године основан Одсек за оријенталистику, захваљујући угледном југословенском оријенталисти, историчару и балканологу, Хасану Калешију (19221976). С обзиром на то да је Х. Калеши био београдски ђак и докторанд, Одсек у Приштини је следио и организациону и наставну схему београдске Катедре. У Приштини је, уз арабистику, посебно била развијана туркологија, због турске националне мањине, а Катедра за турски језик и књижевност се нешто касније и осамосталила. Настава и на Туркологији и на Арабистици одвијала се паралелно на српскохрватском и на албанском језику. Данас се одвија само на албанском језику и нису нам биле доступне информације о њеном раду.

Арапски језик обавезан је предмет и на Факултету исламских наука, који постоји од 1977. године, а од 2013. године постао је део Универзитета у Сарајеву. Четворосеместрална настава арапског језика као обавезног, са четири часа и пет кредита била је 2016, саставни део два програма: Исламске теологије и Исламске вјеронауке и религијске педагогије. Арапски језик је предавао проф. др Мехмед Кицо (19492018), који је дипломирао (1974) и магистрирао (1980; теза: Арабистиика у Прилозима за оријенииалну филолоіију оg 1950. go 1975. ioguнe) на Филолошком факултету у Београду на Катедри за оријенталистику, а докторирао у Сарајеву, на Факултету исламских наука (2002; теза: Ойћелинівистиичка уйеметьена и сиечифична одређень арайске језикословне знаностиu). Поред арапског језика као обавезног, у оба програма постоје и изборни предмети: Увод у арабистику и Конверзација на арапском језику, са три часа и пет кредита. У програмима за 2018. и 2019. годину настава арапског језика 
нешто је разуђенија. У студијском програму Исламске теологије предаје се Арапски језик за теологе I-IV; у програму Исламске вјеронауке и религијске педагогије - Арапски језик за педагоге I-IV, а у Програму за имаме, хабите и муалиме, арапски језик се предаје три семестра кроз предмете: Фонетика и морфологија арапског језика, Синтакса арапског језика и Арапски текстови. У поменутим програмима, као изборни предмет, остао је само Увод у арабистику. Иако у свим програмима на овом Факултету, по природи ствари, преовлађују предмети верског карактера, треба нагласити да су у њих укључени и многобројни врло занимљиви предмети везани за културу, уметност, савремени арапски свет, османску историју, историју и културну историју Балкана... који у студиј уносе нову димензију, употпуњују га и чине изузетно атрактивним и модерним. Поменућемо још и то да се у списку додатне, препоручене литературе налазе и две граматике београдских аутора: Рада Божовића (Udžbenik arapskog jezika sa vježbankom i riječnikom, Sarajevo, 1984) и Дарка Танасковића и Анђелке Митровић (Gramatika arapskog jezika, Beograd, 2005). ${ }^{7}$

Године 1976, на Филозофском факултету у Скопљу, основан је Одсек за турски језик и књижевност, у чијим је плановима и програмима, акценат стављен на савремени турски језик због бројне турске мањиме уМакедонији.

Посебну пажњу заслужује једна од млађих јужнословенских арабистичких катедара - Катедра у Софији. У Бугарској, арапски језик се предаје на Универзитету св. Климент Охридски (основан 1888) од 1964. године у оквиру Програма за оријенталне студије заједно са турским, а од 1974. године у оквиру самосталног програма. Године 2000. отворена је Катедра за арапски језик и семитистику. Од самог почетка рада Катедре у програме основних студија

7 https://fin.unsa.ba/wp-content/uploads/2019/02/FIN-I_ciklus-revizija_ NPP-2016.pdf

https://fin.unsa.ba/wp-content/uploads/2019/10/FIN-NPP-I-ciklus-Islamska-teologija.pdf

https://fin.unsa.ba/wp-content/uploads/2018/12/Vodi\%C4\%87-za-studente-2019-СС2019-1.pdf; странице посећене 5. 5. 2020. 
били су укључени курсеви из арапске историје, арапске књижевности, арапско-исламске цивилизације и културе и исламологије. На мастер студијама постоје два програма везана за Блиски исток и ислам, а на докторским програми везани за арапску лингвистику, арапску књижевност и арапско друштво.

Основне студије су конципиране кроз обавезне и мноштво врло занимљивих и атрактивних изборних предмета. Савремени књижевни арапски језик је један од обавезних предмета на све четири године студија и носи 16 кредита на првој години, 12 на другој и по 10 на трећој и четвртој години. Поред њега, на првој години обавезни предмети су и: Увод у арабистику, Увод у књижевну теорију, Увод у општу лингвистику и Увод у семито-хамитологију. Такође, постоји и више изборних стручних предмета из области семитистике: Историја писама, Друштва и културе древне Арабије, Увод у египтологију, Увод у асирологију, Увод у коптологију, Историја Месопотамије, Историја Египта, Арапска калиграфија и други. На другој години обавезни арабистички предмети су Фонетика и лексикологија арапског језика, Арапска дијалектологија, Морфологија арапског језика, Средњевековна историја арапског света и Нова и савремена историја арапског света. Изборни предмети су подељени на арабистичке: Етапе у развоју арапске филологије (граматичке школе), Творба речи у арапском језику, Куран као литерарно дело, Процват арапско-исламске цивилизације од 9. до 13. века, Историографија и изучавање историјских извора у арапском свету, Класична арапска метрика, Традиционална арапска стилистика, Историја филозофије, Оријенталистика и оријентализам... Уз то, у трећем и у петом семестру могу се бирати још и неки семитски језици: савремени хебрејски (иврит) и амхарски, а поредњих и персијски, турски, свахили, европски језици или руски. На трећој години, нови језички предмет је Синтакса арапског језика, али је акценат на књижевној арабистици где су обавезни предмети: Рана средњевековна арапска књижевност, Касна средњевековна арапска књижевност, Историја арапско-муслиманске филозофије, а изборни, између осталих: Савремена арапска кратка прича, 
Роман у арапској књижевности, Модернизам у арапској књижевности, Превод савремене арапске прозе, Увод у арапску социолингвистику, Мањине у арапском свету... На четвртој години, обавезни предмети су: Савремена арапска култура, Савремена арапска књижевност и Теорија и вештина превођења. Уз њих иде читав низ изборних језичких, књижевних, културолошких и исламолошких куресва, распоређених на трећој и четвртој години, као што су: Проблеми превођења стручних текстова с арапског на бугарски и с бугарског на арапски, Реформа ислама, Савремени ислам, Арапски национализам, Мањине у арапском свету, Арапски идентитет и глобализација, Арапска етнологија, Историја средњевековне арапске медицине, Средства масовних комуникација и функционални стилови у арапском свету... Посебно треба нагласити да су поред књижевног арапског језика, у наставу уведени и регионални говорни језици, наравно, као изборни предмети: сиријски и ирачки (шести семестар) и египатски (седми и осми семестар). Квалитету практичне наставе, свакако, доприносе и изборни предмети као што су симултано и консекутивно превођење (шести и седми семестар), а и чињеница да студенти могу да одлазе на специјализацију у Кувајт, Јордан, Тунис, Мароко, Катар и Египат. Изборни предмети су груписани у модуле: преводилачки, педагошки, египтологија и асирологија. Исход овако узорно конципираног и добро осмишљеног програма јесте, како смо се посредно обавестили, висока говорна продукција, солидно познавање историјских, културних, политичких и религијских прилика на Блиском истоку, као и оспособљеност дипломираних студената за различите врсте послова у дипломатији, туризму, привреди, журнализму... ${ }^{8}$

У Загребу постоји врло развијена Катедра за индологију (од 1959. године), ${ }^{9}$ а блискоисточна оријентали-

8 https://www.unisofia.bg/index.php/eng/the_university/faculties/faculty_of_ classical_and_modern_philology/departments/department_of_arabic_ and_semitic_studies

file://C:/Documents\%20and\%20Settings/Andjelka/My\%20Documents/ Downloads/ArabBakOpisanie.pdf 2. 5. 2020; сајтови посећени 30. 4. 2020.

9 Више о томе види: Zdravka Matišić, „Indologija u Jugoslaviji: Historijat, stanja i perspektive struke“.

Orijentalistika (Ljubljana) 1 (1977): 74-83. 
стика појављује се тек почетком деведесетих година када се отвара Катедра за туркологију, захваљујући сарајевском туркологу професору Екрему Чаушевићу. Године 1993. Вјеће Филозофског факултета Свеучилишта у Загребу донело је одлуку о оснивању ове катедре, а академске 1994/1995. године уписана је и прва генерација студената. Данас је катедра у саставу Одсјека за хунгарологију, туркологију и јудаистику (раније Одсјек за хунгарологију и оријенталистику, односно Одсјеку за хунгарологију и туркологију). Један од предмета на додипломским студијама јесте и Арапски језик (раније Основи арапског језика), који предаје Татјана ПајићВукић, иначе, београдски ђак. ${ }^{10}$

У Љубљани, не Филозофском факултету, при Одсеку за лингвистику (Odelek/Seminar za primerjalno in splošno jezikoslovije in orientalistiko), била је и катедра за оријенталистику, на којој се од половине седамдесетих година изучавају хетитологија, египтологија и арабистика, а нешто касније и персијски језик. Настава арапског и персијског трајала је четири, односно шест семестара. ${ }^{11}$ Данас на овом факултету постоји Катедра за азијске студије (Odelek za azijske študije), на коме се изучавају јапанологија, кореанистика и синологија. Поред катедара на факултету постоје још и центри и течајеви (Centri in tečaji). У оквиру течајева, кроз наставу која траје 60 часова, нуде се курсеви арапског и персијског (почетни) и турског језика (почетни и напредни 1 и 2). ${ }^{12}$

У Европи, арапски језик се учио и учи углавном на универзитетском нивоу. Иста је ситуација, као што смо

10 Више о загребачкој катедри види: Ekrem Čaušević, „Povjest turkologije u Hrvatskoj“, Оријениталистиика јуче-gанас-суйра: зборник раgова; приредила Анђелка Митровић, Београд: ФФ, 2019. 69-77; Anđelko Vlašić, „Povjest turkoloških istraživanja u Hrvatskoj i Katedre za turkologiju“, Časopis za suvremenu povjest 1 (2015): 167-187.

11 Више о томе види: Војаn, С̌op, „Oris slovenske orijentalistike“, Orijentalistika (Ljubljana) 1 (1977): 29-33.

12 http://www.ff.uni-lj.si/studij/oddelki и http://www.ff.uni-lj.si/dejavnosti/ Lezikovni tecaji; страница посећена 1. 12. 2019. 
видели, и на јужнословенским просторима. У 19. веку, када се арабистика коначно конституисала, а број катедара за арапски језик и књижевност знатно увећан, у настави страних језика доминирао је граматичко-преводни метод. Идеје и принципи овог метода у потпуности су одговарали филолошкој концепцији и методичком приступу оријенталним језицима. Све до половине седамдесетих година 20. века и на две највеће катедре за оријенталистику у Југославији, у Београду и у Сарајеву, наставни модели за арапски језик били су базирани на граматичко-преводном методу, а главни уџбеник у тој настави била је Грамайика арайскої језика за ниже разреде меgреса и среgних икола I, II, чији су аутори Ш. Сикирић, М. Пашић и М. Ханџић (Сарајево, 1936 и друга). Вежбања у њој сводила су се на превођење реченица са арапског и на арапски, што је обезбеђивало развијање граматичке и лексичке компетенције, али такав тип вежбања није обезбеђивао никакву говорну продукцију. Школска 1960/1961. година, када је основан Филолошки факултет у Београду издвајањем из Филозофског факултета у самосталну наставно-научну институцију, била је велика прекретница и за југословенску/српску оријенталистику. На Катедри се тада, поред Групе за оријенталну филологију, на којој су се паралелно, све четири године изучавали арапски и турски и арапска и турска књижевност, оснивају и две нове јединице: Група за арапски језик и књижевност и Група за турски језик и књижевност. Формирање две засебне групе отворило је нове развојне могућности Катедре у правцу самосталног развијања арабистике, туркологије и на, одређени начин, и иранологије, као и семитистики и алтаистике. Група за оријенталну филологију и даље је задржана, будући да класична исламолошка концепција оријенталне филологије остаје трајно актуелна на нашим просторима, исто као и потреба за научницима и стручњацима тог профила. Нажалост, реформама, а наша земља се, изгледа, налази у стању перманентне образовне реформе, спроведеним осамдесетих и деведесетих године, Групу за оријенталну филологију је укинута због „окрупњавања образовних профила“. Тиме је нанета велика штета нашој науци јер 
су јој османисти и стручњаци за османску дипломатику, који подједнако добро познају и арапски и турски језик преко потребни за обраду и критичко издавања огромне и разноврсне рукописне заоставштине.

Од шездесетих па све до деведесетих година, број студената арапског језика и књижевности је непрестано растао, због политичке и привредне повезаности Југославије с арапским земљама и потребе државе за арабистима-преводиоцима. Та чињеница изискивала је суштинску реформу и модернизацију наставе арапског језика, али оне нису могле да се десе преко ноћи.

Први озбиљнији помаци у модернизацији наставе арапског језика на београдској Катедри, начињени су реформом образовног система из седамдесетих година, када су уведени нови предмети, као што су: Теорија превођења и Контрастивна анализа српскохрватског и арапског језика, везани за језичку наставу, и неколико предмета чији је циљ био боље упознавање арапске говорне заједнице: Основи исламске цивилизације, Културна историја Арапа, Савремена политичка историја Арапа, Савремена економска географија арапског света. Неки од поменутих предмета из ове друге групе присутни су и данас у настави, у нешто измењеном и осавремењеном облику. Уведени су и смерови, при чему је преводилачки смер на Групи за арапски језик и књижевност био посебно значајан и популаран због великих потраба југословенске привреде за зналцима арапског језика. Уз све то, методика наставе тешко се ослобађала традиционалних окова и приступа, па су студенти на факултету и даље добијали далеко више знања о арапском језику него самог арапског језика.

Корак напред у смислу модернизације наставе, на београдској Групи за арапски језик и књижевност, начиње је крајем двадесетог века. Настава је обогаћена низом нових и занимљивих курсева, новим наставним садржајима и материјалима (Assimil, Linguaphone), лекторским часовима који су омогућавали студентима да чују живу реч и изворни језик, али и да проговоре на књижевном арапском језику. Нови концепт у настави граматике, особито на почетном нивоу, уважавао је, при распореду граматичких 
јединица, структуру и природу арапског језика. При томе, на прво место је извучен глагол и глаголски систем што je, уз интензивније описмењавање студената, омогућило брже и системско усвајање творбених образаца и начина деривације речи у арапском, односно упознавање логике и функционисања на морфолошком плану једног, за велику већину студената, структурно потпуно новог језика. Ове иновације у настави пратила је нова уџбеничка литература, која, поред обавезне текстуалне компоненте, садржи и најразличитије манипулативне вежбе намењене бољем и ефикаснијем усвајању лексике, граматичких категорија и правила, као и вежбе намењене конверзацији. ${ }^{13}$

Док је настава других, пре свега, великих европских језика, обогаћена модернијим и ефикаснијим наставним моделима и методичким приступима, граматичко-преводни метод се у настави оријенталних језика врло дуго примењивао, и то у свом изворном, нимало осавремењеном облику. Тај методички приступ је у случају арапског језика био, а у извесним сегментима наставе, и остао адекватан глотодидактички модел јер омогућава солидно овладавање граматичком структуром, пре свега, стриктно формализованом морфологијом арапског језика, коју карактерише мноштво парадигми за деривацију различитих глаголских и именских облика, што је, заправо, основни предуслов и кључ за стицање рецептивног знања (разумевање и читање писаног језика). Због свега тога, настава арапског језика била је дуго организована на исти традиционалан начин, уз употребу различите класичне граматичко-уџбеничке литературе, базиране на пракси и искуству више генерација европских арабиста.

Један од основних разлога због којих настава арапског језика није на време ухватила корак с резултатима савремене методике наставе страних језика, јесте врло компликована социолингвистичка реалност арапског говорног подручја, којим доминира врло изражена диглосија, односно

13 Види: А. Митровић, Arapski jezik 1: izbor tekstova sa rečnikom, gramatičko-leksičkim komentarima i vežbama, Beograd. 1999 (i 2002; 2007); Arapski jezik 2: Izbor tekstova sa rečnikom, gramatičko-leksičkim komentarima i vežbama, Beograd. 2001 (i 2005). 
коегзистенција и истовремена употреба два формално и функционално различита варијетета једног језика у оквиру исте језичке заједнице. „Виши” варијетет, књижевни арапски језик - класични и модерни/стандардни (ap.al-luga al-fusha), функционише као општеприхваћени писани језички стандард, а „нижи” (ap. al-luggaal-‘miyya) обухвата регионалне говорне арапске дијалекте. Уз то, у говорној пракси постоји више различитих варијетета и регистара, међу којима се издваја тзв. „трећи” или „средњи“ арапски (ap. al-lugaal-'arabiyyaal-țalita), који представља посредника између два пола диглосије, односно функционалну мешавину формалног писаног стандарда и неформалних локалних дијалеката, а којим се у усменој комуникацији служе образовани Арапи. ${ }^{14}$

14 Од шездесетих година двадесетог века па надаље, арапска диглосија постала је предмет лингвистичких, првенствено социолингвистичких интересовања. а за ову прилику издвајамо значајније радове, од којих су неки данас класика: S. J. Altoma, The Problems of Diglossia in Arabic, Cambridge-Massachusec, 1969, A. F. Beeston, The Arabic Language Today, London, 1970; M. R. Berger, "Diglossia within a General Theoretical Perspective: Charles Ferguson's Concept 30 Years Later", Multilingua (1990): 285-295; H. Blanc, Communal Dialects in Baghdad, Harvard, 1964; H. B., "Stylistic Variations In Spoken Arabic: A Sample of Interdialectal Educated Conversation", Contributions to Arabic Linguistics 9 (1960): 81-161; J. Blau, “The Beginnings of the Arabic Diglossia: A Study of the Origins of Neo-Arabic“, Afro-Asiatic Lingiustics 4 (1977): 175-202; K. Brustad, The Comparative Syntax of Four Arabic Dialects: An Investigation of Selected Topics, Harvard, 1991; W. Diem, Hocharabisch und Dialekt im Arabischen: Untersuchungen zur heutige arabischen Zweisprächigkeit, Wiesbaden, 1974; Ch. Ferguson, „Diglossija“, Word 15 (1959): 325-340; "Myths about Arabic", Readings in Sociology of Language, ed. J. Fishmann, London, 1970, 375-381; R. S. Harrell, The Phonology of Colloquial Egyptian Arabic, New York, 1957; T. F. Mitchell i S. A. al-Hassan: Modality, Mood, and Aspect in Spoken Arabic: with Special reference to Egypt and the Levant. London: New York, 1994; T. F. Mitchell, Colloquial Arabic: The Living Language of Egypt, London, 1962; V. Monteil, L'Arabe modern, Paris, 1960; N. Tomiche, »Les Parlers arabes d'Egypte«, Etudes d'orientalisme dédiées à la memoire de Levi-Provinçale, T. II, 1962, 767-779; N. T., Les Parlers arabe du Caire, Paris, 1964; M. R. Zughoul, „Diglossia in Arabic: investigating solutions“, Anthropological Linguistics 22 (1980): 201-217. Наш арабиста С. Јанковић такође се систематски и студиозно бавио диглосијом у арапском и оставио неколико значајних радова, од којих издвајамо: „Diglosija - sociolingvistički fenomen suvremenog 
Савремени књижевни арапски језик/стандардни арапски језик, изданак класичног арапског језика, мада се најчешће одређује као општеприхваћени писани језички стандард, није јединствен јер се у њему осећа утицај локалних дијалеката. Он је језик већине средстава информисања, науке, литературе, језик међуарапске комуникације, језик духовног и културног наслеђа арапско-исламске цивилизације, надасве језик ислама и Курана.

Говорни арапски дијалекти одавно егзистирају у арапској говорној заједници, заправо, откако се зна за арапски језик (Janković 1978: 152). Употребљавала су их неколико векова пре Христа разна арапска племена, која су живела на Арабијском полуострву, матичном подручју арапског језика. На основу већег броја говорних дијалеката створен је јединствен језички модел - соіпе, који је садржао најизразитије одлике говорног језика. Данас су говорни дијалекти битан и активан чинилац у арапској језичкој стварности. Дијалекти се разликују од једне до друге земље, шта више од региона до региона унутар једне земље. У оквиру тога, разликују се говори града и села, номадског и седелачког становништва, различитих социјалних класа и група, етничких и верских заједница... Дијалекат је, заправо, матерњи језик сваког Арапина. То је језик свакодневне комуникације. Средства јавног информисања у арапским земљама, уместо да се боре за правилан књижевни језик, обилато користе дијалекте у различитим емисијама, па су говорни идиоми врло присутни у радио и TV програмима. Овај варијетет је данас будући готово неизбежан у дијалозима приповедака, новела и романа, због једноставних конструкција и

arapskog“, Radio Sarajevo - Treći program 20 (1978): 142-177, „Polovi diglosije u arapskom“, Prilozi za orijentalnu filologiju 14 (1975): 283-300 i Diglosija u savremenom arapskom: Na materijalima književnog arapskog i egipatskog kolokvijalnog arapskog (doktorska teza, Sarajevo, 1975).

Корак даље у бављењу диглосијом јесте увођење арапских говорних језика у академску наставу - на јужнословенским просторима у Софији и у Београду - кроз курсеве Арапска дијалектологија на софијској катедри, односно Увод у арапске дијалекте (био у наставним програмима београдске Катедре од 2006. до 2014. године), као и курсеве главних арапских дијалеката. 
експресивне снаге. У овако сложеној језичкој ситуацији, врло тешко је креирати адакватан глотодидактички модел који би омогућио ефикасну наставу арапског језика и стицање и развијање граматичке, као и, практично, двојне комуникативне компетенције. Решења за тај проблем се стално траже, а, с времена на време, нуде се и нови методички приступи.

Последњих деценија 20. века интересовање за студије арапског језика нагло је порасло због промене, пре свега, политичких, гео-политичких и друштвено-економских односа у свету, при чему су Арапи почели да играју све значајнију улогу на светској политичкој и економској сцени. Говорна заједница арапског језика обухвата десетак држава, које се налазе на простору северне Африке и Предње Азије. Све оне, упркос свим, често врло израженим разликама, због својих религијских, етничких, језичких и геополитичких особености чине једну релативно хомогену целину. Овај простор значајан је у цивилизацијском смислу јер је колевка неколико великих древних цивилизација - египатске, сумерске, асирско-вавилонске, арамејске, феничке, јеврејске, персијске и других, а такође, и трију великих монотеистичких религија - јеврејске, хришћанске и исламске.

Са економског становишта Блиски исток, као стециште важних трговачких, путева, особито оних на Путу свиле, од давнина игра значајну улогу. Многобројна природна рудна богатства, пре свега, нафта, чијим огромним изворима и резервама арапске земље данас располажу, извор су њиховог благостања и високог животног стандарда. Економском напретку арапских земаља доприноси и њихова велика туристичка експанзија.

Подручје Блиског исток било је и остало поприште више конфликата и ратова, као што су вишедеценијски арапско-израелски сукоб, ирачки рат, рат и перманентно тињајућа криза у Либану, рат у Сирији... Неке арапске земље и њихови режими помињу се данас и као главни извори, подстрекачи и финансијери глобалног тероризма.

Све то скупа ставља 'арапску домовину', како сами Арапи зову овај простор, у средиште свих светских 
економских, политичких, културних и научних токова. Отуда је, последњих деценија, арапски, што се учења тиче, постао један од најтраженијих језика у Америци и Европи.

У том смислу, су постављени и нови циљеви језичке наставе, међу којима најистакнутије место заузима активно владање језиком, пре свега, у сфери писане продукције, а сходно томе, уведена је и нова методика учења језика, заправо, један арапском језику и одређеној ситуацији прилагођен еклектички приступ, у оквиру кога се много више пажње поклања продуктивним језичким вештинана и развијању комуникативне, а уз то и социокултурне компетенције.

Узимајући у обзир језички репертоар арапског говорног подручја, већ на првом кораку у настави намеће се сасвим логично, изгледа, у светској арабистици, трајно актуално питање: Који арайски језик учийи? - „виши” или „нижи” варијетет - модерни стандардни арапски или говорне дијалекте? Модерни стандардни арапски језик је био и остаће централни део наставе, а радикално осавремењавање наставног процеса, започето седамдесетих година 20. века, незаустављиво тече и хвата корак с временом и потребама модерних друштава, у којима доминирају глобализација, велика експанзија комуникационих и информационих технологија, као и потребе за функционалним образовањем и конкретним знањима. Последњих петнаестак година говорни чин добија све значајније место и у наставној пракси и у уџбеницима и приручницима, у којима текстуалне компоненте, везане за ситуације из свакодневног живот, за специфични арапско-исламски социо-културни миље, арапску књижевност, историју, географију, културну традицију, савремене културне феномене и слично, укључују и најразличитије манипулативне вежбе намењене бољем и ефикаснијем усвајању лексике, граматичких категорија и правила, као и елеменате конверзације. Међутим, до данас, на пољу глотодидактике није пронађен ниједан свеобухватан наставни модел који би омогућио стицање и развијање практично двојне језичке компетенције, као и комуникативне компетенције.

„С обзиром на то да је општи идеални циљ наставе сваког страног језика постизање језичке способности својствене 
изворном говорнику језика који се учи или бар приближавање таквом типу способности, требало би очекивати да систем наставе арапског језика омогући досезање описане диглосијалне комплексне језичке моћи" (Tanasković 1980: 64). Стога се, у едукативној пракси све више траже решења која ће повезати полове диглосије, уз увођење, у одређеном обиму, и елемената главних говорних дијалеката.

Наша оријенталистика, још од својих повоја, настојала је да следи главне светске научне токове, али и да прати многобројне домаће реформске процесе и друштвене потребе. Србија се 2003. године, потписивањем Болоњске декларације, прикључила европској академској заједници и нашла се пред радикалном реорганизацијом и усклађивањем свог система високог образовања с европским. Филолошки факултет Универзитета у Београду укључио се у нове токове школске 2005/2006. године, од када и студенти Групе за арапски језик, књижевност и културу студирају по новим, радикално измењеним наставним плановима и програмима. То практично значи да су стари, филолошки структурисани програми, који су подразумевали изучавање само арапског језика и књижевности, обогаћени културолошко-цивилизацијском димензијом, односно бројним предметима везаним за арапско-исламску цивилизацију. И сама настава арапског језика и књижевности претрпела је одређене измене у смислу увођења нових предмета, нове методике и нових садржаја, при чему је акценат стављен на лингво-културолошки приступ што, свакако, доприноси паралелном развијању укупних језичких способности студената и опште, тј. социо-културне компетенције. Кроз добро одабран и разноврсан педагошки материјал и дијалошка штива студенти данас стичу граматичку и лексичку компетенцију, унапређују усмену и писмену језичку продукцију на арапском језику и ефикасно савладавају одређене језичке нивое. Истовремено, систематски и свеобухватно упознају све сегменте арапске говорне заједнице и један, за већину студената, посве нов и непознат цивилизацијски круг, односно стичу сва неопходна знања и информације о географији, историји, култури, уметности, филозофији, религијском систему/системима, 
привреди, систему вредности арапских друштава, школском систему, правном систему, свакодневним стиловима живота, фолклору, народним веровањима, гастрономији... (Mitrović $2008,2006)$. Како смо видели, врло слично је постављен и бугарски арабистички модел.

Настава на основним студијама организована је кроз једносеместралне обавезне предмете: Савремени арапски језик Г1-Г8, Морфологија арапског језика 1-2, Фонетика арапског језика 1-2, Морфосинтакса арапског језика 1-2, Синтакса арапског језика 1-2, Арапски језик - теорија превођења, Арапски језик - вештина превођења, Језик арапских медија, Пословни арапски језик и кореспонденција, Класична арапска књижевност 1-2, Савремена арапска књижевност 1-2, Основи исламске цивилизације 1-2 и Увод у оријенталистику 1-2. Другу групу предмета чине стручни арабистички изборни предмети: арапски дијалекти, Арапски језик - стручна терминологија, Арапски језик - граматичка терминологија, Историја арапског језика, Савремена књижевност Магреба 1-2, Драмска књижевност код Арапа 1-2, Мемоарска проза код Арапа 1-2, Ислам и хришћанство, Исламски фундаментализам, Исламска филозофија, Основи исламског права, Исламска уметност, Исламска архитектура, Арапска калиграфија, Савремени арапски свет 1-4... На дипломским академским студијама - мастер, постоје изборни предмети: Арапска лексикографија, Неарапски ислам и Европски колонијализам и арапски свет, а на докторским академским студијама: Лингвистичка арабистика 1-4, Књижевна арабистика 1-4 и Исламска цивилизација/култура на Балкану 1-4. У овако мултидисциплинарно и интердисциплинарно конципираном програму студија, повезивањем лингвистичке и књижевне арабистике с већим бројем различитих дисциплина, пре свега с исламологијом, направљен је велики квалитативан помак у настави. У поређењу са претходним програмима, да̂ се запазити да је доста новина унето у наставу књижевности, која је деценијама, све до последње реформе садржала само два основна курса - класичну и модерну арапску књижевност. Седамдесетих година, уз предавања из књижевности уведене су и вежбе које су обухватале 
илустрације, односно читање и превођење одабраних страница и одломака књижевних дела. Последња реформа унела је у програм неколико нових изборних предмета на којима се обрађују поједини занимљиви сегменти богате арапске литерарне баштине, а илустрације из књижевности обогатила новом методиком наставе која обухвата усмену и писмену продукцију на арапском језику.

Међутим, најрадикалнију иновацију програма, и то далеко ширу него у Бугарској, представља увођење у наставу арапских говорних језика: египатског, ирачког, сиријског и магрепских дијалеката, ${ }^{15}$ који спадају у групу изборних предмета, заузимају истакнуто место у језичкој настави и, временом, су постајали све популарнији међу студентима. Двосеместрални курсеви дијалеката омогућују студентима да упознају фонетско-фонолошке, морфолошке и синтаксичке карактеристике главних арапских дијалеката, као и да усвоје лексику и фразе намењене свакодневној комуникацији. За потребе наставе египатског дијалекта састављен је и уџбеник Екалем масри 1 (Београд, 2011), чији је аутор Иман Јарић, лектор за арапски језик на Катедри. Овај приручник са 15 лекција у којима су текстуално и лексички представљени различити конверзациони контексти и животне тематско-ситуационе целине, користан је и незаобилазан сапутник свима онима који желе да продру у тајне овог, у арапском свету, свакако, најзначајнијег и најкоришћенијег дијалекта. Посебно треба нагласити чињеницу да на београдској Катедри данас постоје одлични кадровски услови за наставу дијалеката - лектори из свих значајнијих делова арапског света. У врло блиској будућности, студенти ће моћи да уче и нове дијалекте - либијски и палестински.

Београдска Катедра за оријенталистику је „пружила нашој култури и науци значајне кадрове и резултате, бројна научна и стручна дјела. Велики је број актуелних посленика

15 Први универзитетски курсеви арапских говорних дијалеката јављају се у Европи тек у 19. веку. Национална школа за живе оријенталне језике (Ecole nationale des languages orientales vivantes) у Паризу једна је од првих универзитетских установа у Европи на којој су 1821. године уведени курсеви источних и западних арапских дијалеката. 
у области арабистике и оријенталистике уопште који су се школовали на овој Катедри, стицали своје стручне и научне степене, остајали у Београду или одлазили у друге центре да наставе и унаприједе оно што су овде започели. Извјестан број њених некадашњих студената постали су наши најеминентнији научни радници-оријенталисти, а и сами наставници те Катедре су дали озбиљан прилог нашој арабистици. Најзад знатан број некадашњих студената ове Катедре ради успјешно на пословима у јавном животу наше земље, у науци, култури, образовању, информацијама, привреди, трговини, у друштвено-политичким организацијама, у представништвима у иностранству" (Grozdanić 1975: 37).

\section{Извори и литература}

Vukomanović, Milan. „Zapad i islam“. Milan Vukomanović i Marinko Vučinić (ur.). Religijski dijalog: Drama razumevanja. Beograd: Beogradska otvorena škola, 2003. 20-32. Štampano.

Grozdanić, Sulejman. „Arabistika u socijalističkoj Jugoslaviji (19451975)“. Orijentalistika (Ljubljana) 1 (1975): 36-41. Štampano.

Ђукановић, Марија. „Катедра за оријенталну филологију“. Сӣo іоgина Филозофскоі Факулиетейа. Београд: Филозофски факултет, 1963. 477-484. Штампано.

Janković, Srđan. „Diglosija - sociolingvistički fenomen savremenog arapskog“. Radio Sarajevo - Treći program 20 (1978): 142-177. Štampano.

Jauk Pinhak, Milka. „Problemi orijentalistike kao znanosti“. Orijentalistika (Ljubljana) 1, (1977): 8-19. Štampano.

Mitrović, Anđelka. „Multidisciplinarnost u nastavi arapskog jezika“. Julijana Vučo (ur.). Multidisciplinarnost u nastavi jezuka i književnostu: zbornik radova. Podgorica: Nikšić: Univerzitet Crne Gore, Filozofski fakultet, 2008. 213-228. Štampano.

Mitrović, Anđelka. „Nastava arapskog jezika i reforma obrazovanja“. Julijana Vučo (ur.).

Nastava jezika u reformi obrazovanja: zbornuk radova. Nikšić: Filozofski fakultet; Podgorica: Univerzitet Crne Gore, 2006. 138-160. Štampano.

Окић, Тајиб. „Оријенталистика у Југославији“. Преїлеg VIII, X, 127128 (1934): 403-404. Штампано. 
Ramić, Jusuf. „Izučavanje arapskog jezika kod nas“. Omer Nakićević (ur.) Zbornik radova Islamskog teološkog Fakulteta. Sarajevo: Islamski teološki fakultet, 1987. 237-268.

Štampano.

Rodinson, Maxime. "The Western Image and Western Studies of Islam". Joseph Schacht(ed.) The Legacy of Islam. Oxford: Oxford University Press, 1974. 9-62. Štampano.

Tanasković, Darko, „Jugoslovenska orijentalistika između filologije i lingvistike". Radio Sarajevo - Treći program XIV, 15(1986): 55-76. Štampano.

Танасковић, Дарко. „Који арапски језик учити?“. Филолошки йреiлеg 18, 1-4 (1980): 63-71. Штампано.

\title{
Andjelka Mitrovic
}

\author{
TEACHING OF THE ARABIC LANGUAGE AND \\ LITERATURE IN THE SOUTHERN SLAVIC REGIONS
}

\section{Summary}

The history of the European Oriental Studies as well as Arabic studies, of which Yugoslav and Serbian Oriental Studies / Arabic Studies are important part, goes back for many centuries. The beginning of teaching Arabic in Europe has started in $13^{\text {th }}$ century and had been organizationally linked to the Holy Seat. The first secular Department of Oriental Studies was founded in Paris at the College of France in 1539. Oriental languages have a long tradition in the Southern Slavic regions as well. During $15^{\text {th }}$ and $16^{\text {th }}$ centuries most of the South Slav territories fell under the Ottoman rule. Process of conversion to Islam, which has begun with the Ottoman rule, also imposed a new system of education, and within it teaching of the main Oriental languages - Arabic, Turkish and Persian. At the university level, Arabic studies had begun with the opening of the Seminar of Oriental Philology in Belgrade (1926), the first such university department in the Balkans. Much later two more Arabic departments were established - in Sarajevo (1950) and Pristina (1973). For decades, the mentioned departments have been using the traditional teaching practices focus- 
ing on literary Arabic and grammatical translation. The real modernization of Arabic teaching began in Europe and our region since the mid-1970s. The result is that Linguistic Arabic Studies today has become a modern and effective interdisciplinary study in accordance with the requirements of modern times and society.

Key Words: Oriental studies, Arabic, Arabic literature, Teaching models, Departments, Belgrade, Sarajevo, Sofia 